\title{
LIBROS
}

\section{Manual de Protocolo}

M. a del Carmen Portugal Bueno, Valencia, Tirant lo Blanch, 178 págs.

\section{MANUAL \\ DE PROTOCOLO}

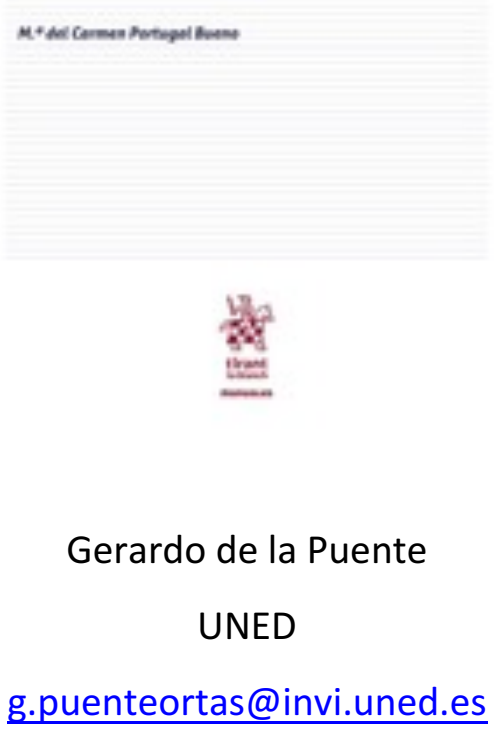

Recepción: 17/04/2017 Revisión: 14/05/2017 Aceptación: 12/06/2017 Publicación 30/06/2017 
Ma del Carmen Portugal, es doctora en comunicación y profesora de Derecho premial en el Máster Universitario en Protocolo en la UNED, que ya cuenta entre sus obras científicas un estudio sobre la normativa de derecho premial del Estado y de las Comunidades Autónomas.

Esta obra, complemento de la anterior, presenta una estructuración en base a la propia configuración del Estado. Por ello y como punto de partida en el capítulo 1 se constata cuál es la organización del Estado español y su división en municipios, provincias y comunidades autónomas, efectuando una relación de todas ellas que ayuda a cualquier lector a introducirse en el conocimiento de las instituciones administrativas del Estado.

Partiendo, en el capítulo 2 del análisis de la figura del reglamento como norma jurídica general y con rango inferior a la ley por una autoridad en forma de una serie ordenada de reglas y preceptos, (p.22), pasa a continuación centrarse en el reglamento de honores y distinciones, comprobando su objeto, carácter, clasificación, distinción, objetos, insignias, descripción, otorgamientos, procedimiento para su concesión. Se realiza un estudio exhaustivo del motivo de las recompensas honoríficas, su distinción, el procedimiento de concesión y el registro de honores.

En los siguientes capítulos se exponen los diferentes honores y distinciones en las diferentes comunidades autónomas: en el capítulo 3 los honores y distinciones del País Vaco; en el capítulo 4, los honores y distinciones en Cataluña; en el capítulo 5 las medallas de Galicia; en el capítulo 6, la normativa sobre el hijo predilecto y la medalla de Andalucía; en el capítulo 7 los honores y distinciones del Principado de Asturias; en el capítulo 8, los títulos y las condecoraciones de Cantabria; en el capítulo 9, las distinciones del Gobierno de la Rioja; en el capítulo 10 los títulos y condecoraciones de la Región de Murcia; en el capítulo 11, los honores de la Comunidad Valenciana; en el capítulo 12, los reconocimientos honoríficos de Aragón; en el capítulo 13 las distinciones honoríficas del Gobierno de Castilla la Mancha; en el capítulo 14 las medallas de oro de Canarias; en el capítulo 15 las medallas y cruz de la Comunidad Foral de Navarra; en el capítulo 16 las medallas de Extremadura; en el capítulo 17 Las distinciones honoríficas de las Islas Baleares; en el capítulo 18 la orden y la medalla de la Comunidad de Madrid; en el capítulo 19 las medallas de Castilla y León y de sus Cortes; en el capítulo 20 los honores de las Ciudades Autónomas de Ceuta y Melilla y en el capítulo 21 se relacionan los premios oficiales de las diferentes comunidades autónomas.

En el análisis de los honores, condecoraciones, medallas, distinciones y premios de las diferentes comunidades autónomas que se realiza en este libro se relacionan las normas en las que se basan, se describe su forma y se incluyen imágenes de las medallas y cruces que se conceden, que es muy de agradecer que se publiquen a todo color. El libro representa una obra de consulta necesaria para saber que honores y distinciones existen en las diferentes comunidades autónomas y en qué casos se conceden, siendo una obra que permite a 
cualquier persona, no solo a los expertos, a saber y conocer de una forma sencilla y amena los honores y distinciones que se conceden dentro de estado español.

Tenemos que manifestar que el nombre de la obra no nos parece muy acertado, por cuanto se nos indica que es un manual de protocolo, cuando en realidad estamos ante una obra de derecho premial en el ámbito de las comunidades autónomas, con carácter fundamentalmente descriptivo. Hubiese sido recomendable que la editorial hubiera incluido un subtítulo, que sabemos a ciencia cierta que la autora indicó, pues tal y como figura puede inducir a error en los lectores más profanos. Aun así, esta obra se convierte en un instrumento indispensable en la biblioteca de protocolistas y juristas. 
(C) () 